\title{
Distinction between clonal and paraclonal cutaneous involvements in VEXAS syndrome
}

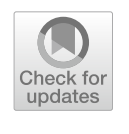

Valentin Lacombe ${ }^{1,2^{*}+}$, Annaelle Beucher ${ }^{3,4 \dagger}$, Geoffrey Urbanski ${ }^{1,2}$, Yannick Le Corre ${ }^{5}$, Laurane Cottin ${ }^{3,6}$, Anne Croué ${ }^{7}$ and Anne Bouvier 3,4

\begin{abstract}
VEXAS (vacuoles, E1 enzyme, X-linked, auto-inflammatory, somatic) syndrome is an inflammatory disorder with hematological and systemic features. A recent study demonstrated that the dermal infiltrate in neutrophilic dermatosis from VEXAS patients is derived from the pathological UBA1-mutated myeloid clone. Neutrophilic dermatosis is, however, only one of the various skin involvements observed in VEXAS syndrome. We analyzed 10 formalin-fixed paraffin-embedded skin biopsies from genetically confirmed VEXAS syndrome. UBA1 mutation was found in the biopsies related to neutrophilic dermatitis but in none of the other histological patterns (leukocytoclastic vasculitis and septal panniculitis). This could lead to a distinction between clonal and paraclonal cutaneous involvements in VEXAS syndrome, which could in turn improve therapeutic outcomes.
\end{abstract}

Keywords: Autoinflammatory diseases, Sweet syndrome, Vasculitis, Clonal hematopoiesis, Mutation

\section{To the Editor,}

VEXAS (vacuoles, E1 enzyme, X-linked, auto-inflammatory, somatic) syndrome is a recently described adultonset inflammatory disorder with various involvements including arthritis, chondritis, cutaneous features, macrocytic anemia and myelodysplastic syndrome [1-4]. Zakine et al. recently performed molecular analyses on 8 paraffin-embedded skin tissue sections of neutrophilic dermatosis in patients with VEXAS syndrome [5]. They identified $U B A 1$ mutations in all of these skin samples. This was the first study to demonstrate a strong link between the presence of UBA1-mutated cells in an involved tissue (except for bone marrow) and the related clinical manifestations. According to the author's conclusion, this suggests that the dermal infiltrate in VEXAS skin lesions is derived from the pathological myeloid

\footnotetext{
*Correspondence: lacombe.valentin31@gmail.com

† alentin Lacombe and Annaelle Beucher contributed equally to this work

${ }^{1}$ Service de Médecine Interne et Immunologie Clinique, Centre Hospitalier Universitaire, 4 rue Larrey, Angers, France

Full list of author information is available at the end of the article
}

clone, which could be targeted to treat VEXAS patients with cutaneous involvement.

Neutrophilic dermatosis is, however, only one of the various skin involvements observed in VEXAS syndrome. Indeed, leukocytoclastic vasculitis, erythema nodosa and periorbital edema have also been reported in this rare and recently described disorder [1]. Consequently, we aimed to assess the presence and abundance of the UBA1-mutated clone in the different cutaneous involvements related to VEXAS syndrome.

We retrospectively analyzed the medical record of 6 patients with both genetically confirmed VEXAS syndrome (UBA1 mutation identified from blood samples, $U B A 1$ variants detailed in Table 1 ) and related skin involvement with formalin-fixed paraffin-embedded skin biopsies performed between January 2017 and September 2021 in Angers University Hospital. Two methods of dewaxing and DNA extraction were used (Kit NucleoSpin Tissue and NucleoSpin DNA FFPE XS, Macherey Nagel, Düren, Germany). The quality and quantity of the extracted DNA samples were evaluated using a NanoDrop 1000 spectrophotometer (Thermo original author(s) and the source, provide a link to the Creative Commons licence, and indicate if changes were made. The images or other third party material in this article are included in the article's Creative Commons licence, unless indicated otherwise in a credit line to the material. If material is not included in the article's Creative Commons licence and your intended use is not permitted by statutory regulation or exceeds the permitted use, you will need to obtain permission directly from the copyright holder. To view a copy of this licence, visit http://creativecommons.org/licenses/by/4.0/. The Creative Commons Public Domain Dedication waiver (http://creativeco mmons.org/publicdomain/zero/1.0/) applies to the data made available in this article, unless otherwise stated in a credit line to the data. 
Table 1 Clinical and histological features of included patients and biopsies, and results of the DNA extraction and sequencing

\begin{tabular}{|c|c|c|c|c|c|}
\hline $\begin{array}{l}\text { Skin biopsy } \\
\text { specimen } \\
\text { number }\end{array}$ & $\begin{array}{l}\text { Treatment at the time of } \\
\text { the biopsy }\end{array}$ & Clinical features & Histological pattern & $\begin{array}{l}\text { DNA extraction } \\
\text { of quality? }\end{array}$ & $\begin{array}{l}\text { Sanger } \\
\text { sequencing } \\
\text { results }\end{array}$ \\
\hline \multicolumn{6}{|c|}{ Patient \#1 (male, 78 years-old, UBA1 mutation p.Met41Thr) } \\
\hline No. 1 & None & Erythema nodosum & Septal panniculitis & Yes & UBA1-wild type \\
\hline No. 2 & None & Erythema nodosum & Septal panniculitis & Yes & UBA1-wild type \\
\hline No. 3 & Cortancyl & Papules & Neutrophilic dermatosis & Yes & UBA1-mutated \\
\hline \multicolumn{6}{|c|}{ Patient \#2 (male, 72 years-old, UBA1 mutation p.Met41Thr) } \\
\hline No. 1 & None & Papules & Leukocytoclastic vasculitis & No & NA \\
\hline \multicolumn{6}{|c|}{ Patient \#3 (male, 63 years-old, UBA1 mutation p.Met41Leu) } \\
\hline No. 1 & Methotrexate & Papules, nodules & Leukocytoclastic vasculitis & Yes & UBA1-wild type \\
\hline No. 2 & Methotrexate, abatacept & Papules, purpura & Leukocytoclastic necrotizing vasculitis & Yes & UBA1-wild type \\
\hline No. 3 & Etanercept & Papules & Neutrophilic dermatosis & Yes & UBA1-mutated \\
\hline \multicolumn{6}{|c|}{ Patient \#4 (male, 64 years-old, UBA1 mutation p.Met41Val) } \\
\hline No. 1 & None & Erythema nodosum & Septal panniculitis & No & NA \\
\hline No. 2 & None & Livedo & Subnormal & No & NA \\
\hline \multicolumn{6}{|c|}{ Patient \#5 (male, 87 years-old, UBA1 mutation p.Met41Val) } \\
\hline No. 1 & None & Macules, purpura & Leukocytoclastic vasculitis & No & NA \\
\hline
\end{tabular}

Fisher Scientific, Waltham, USA). In case of sufficient DNA quantity and quality $(260 / 280 \mathrm{~nm}$ absorbance ratio between 1.8 and 2.0), somatic mutations in UBA1 (NM_003334.3) [1, 6] were then screened by Sanger sequencing (BigDye ${ }^{\mathrm{TM}}$ Terminator v3.1 Cycle Sequencing Kit with 3130xl genetic analyzer, Applied Biosystems ${ }^{\mathrm{TM}}$, USA), as previously described [7]. The minimal variant allele frequency (VAF) allowing UBA1 mutations to be detected with Sanger sequencing was determined to be $10 \%$ by diluting $U B A 1$-mutated DNA samples with known VAF assessed by Next Generation Sequencing.

Ten skin biopsies were performed in the period of interest and involved either erythema nodosum, papules, nodules, purpuric macules or livedo. The clinical, molecular and pathological pattern of the included patients and biopsies were detailed in Table 1 . The DNA extraction allowed sequencing in 6/10 samples from biopsies with the following histological patterns: 2 neutrophilic dermatosis (intense and diffuse neutrophilic infiltrate with no evidence of infection or vasculitis), 2 leukocytoclastic vasculitis (angiocentric segmental inflammation with fibrinoid necrosis and neutrophilic infiltrate with karyorrhexis in the small vessel walls), and 2 septal panniculitis (inflammatory cell infiltrate at the periphery of the hypodermal lobules). UBA1 mutation was found in the 2 biopsies related to neutrophilic dermatitis but in none of the other histological patterns (Figure 1). The mutational load was higher in neutrophilic dermatosis (>50\%) than in blood or bone marrow samples $(<50 \%)$ from the same patient. Associated hematological features were as follows: anemia (6/6), macrocytosis (4/6), thrombocytopenia (3/6), neutropenia (3/6), lymphopenia $(3 / 6)$ and myeodysplastic syndrome $(2 / 6$, patients \#1 and \#4).

Previous studies specified the clinical contexts that should lead to searching for a $U B A 1$ mutation in blood or marrow samples to confirm suspected VEXAS syndrome [4, 8], and demonstrated that the UBA1 mutated myeloid clone may also infiltrate the VEXAS-related skin lesions [5]. In our pilot study, we confirmed the presence of UBA1-mutated cells in skin tissues in cases of neutrophilic dermatosis. However, we did not identify any $U B A 1$ variation in the four other biopsies with different histological patterns despite a sensitivity to identify the mutation in case of $>10 \%$ mutated cells. While we cannot rule out the idea that the absence of UBA1 mutation was related to a lower myeloid infiltrate in non-neutrophilic dermatosis lesions, we demonstrated that the UBA1mutated clone is either absent or much less abundant in non-neutrophilic dermatosis skin lesions. We could hypothesize the distinction between "clonal" (neutrophilic dermatosis) and "paraclonal" (leukocytoclastic vasculitis and septal panniculitis) cutaneous involvements in VEXAS syndrome. This could result in different treatment options using clonal-depleting therapy in neutrophilic dermatosis, whereas paraclonal involvements could be treated with drugs targeting the inflammation and cytokine release. Indeed, Commont et al. recently showed promising results about the efficiency of azacitidine for treating patients with VEXAS syndrome [9]. This type of treatment could be particularly useful in patients with clonal involvements. 


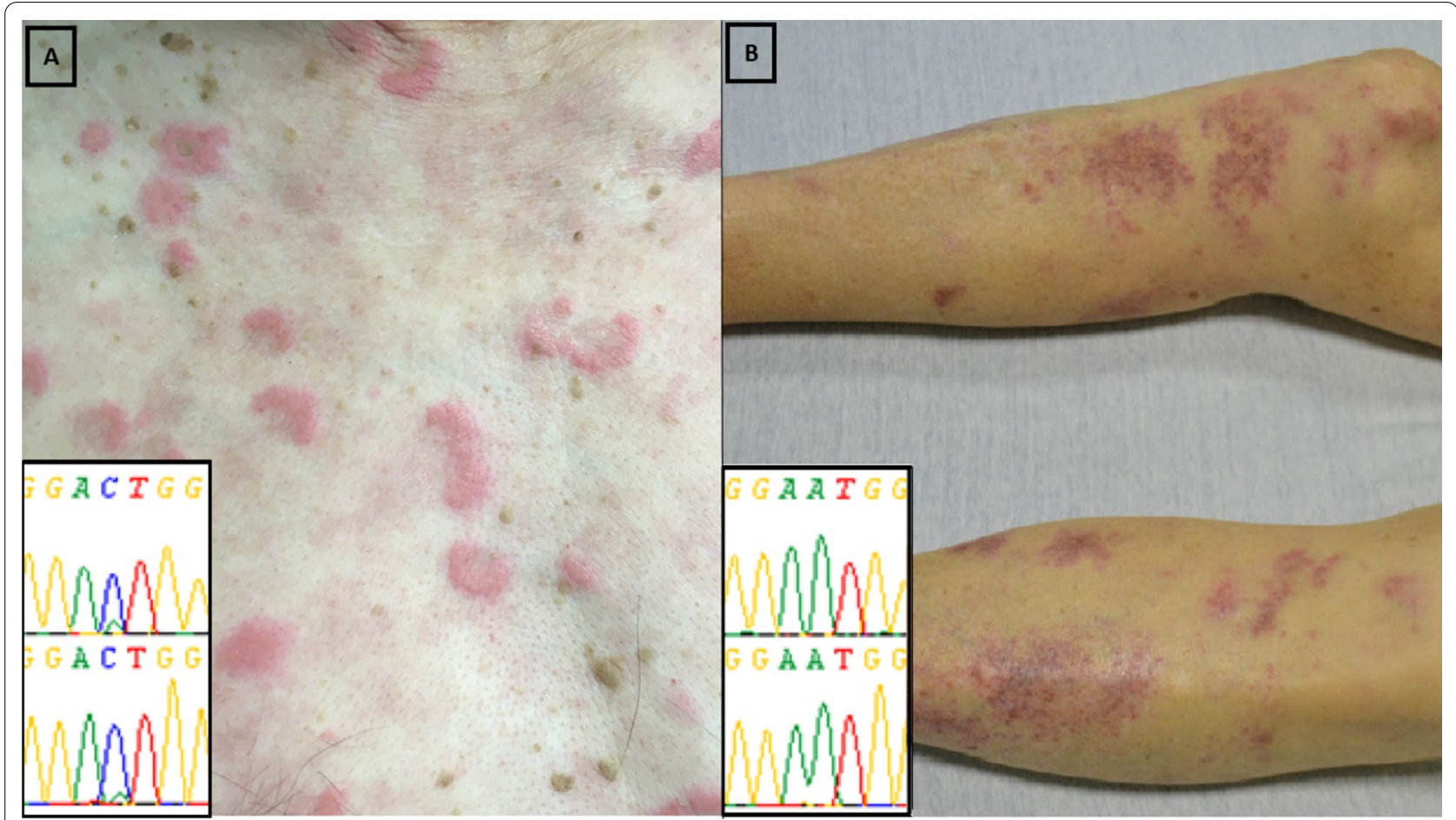

Figure 1 Results of molecular analysis with Sanger sequencing according to the type of skin involvement. A presents the UBA1 mutation (p.Met41Leu, c.121A>C, mutational load >50\%) observed with Sanger sequencing from a skin biopsy in a patient with VEXAS syndrome and neutrophilic dermatosis. B presents the UBA1-wild type gene observed in a skin biopsy in a patient with VEXAS syndrome and leukocytoclastic vasculitis

In conclusion, the $U B A 1$-mutated clone was observed in VEXAS-related skin involvement in cases of neutrophilic dermatosis but not in other histological patterns. This could lead to a distinction between clonal and paraclonal cutaneous involvements in VEXAS syndrome, with which could in turn improve therapeutic outcomes.

\section{Abbreviation}

VAF: variant allele frequency.

\section{Acknowledgements}

None.

\section{Authors' contributions}

VL contributed to the study conception and design, analysis and interpretation of data, drafted the manuscript and critically revised the manuscript for important intellectual content. $A B, L C, A C$ and $A B$ contributed to the acquisition, analysis and interpretation of data and critically revised the manuscript for important intellectual content. GU and YLC contributed to the interpretation of data and critically revised the manuscript for important intellectual content. All authors read and approved the final manuscript.

\section{Funding}

None.

\section{Availability of data and materials}

The datasets used and/or analyzed during the current study are available from the corresponding author on reasonable request.

\section{Declarations}

\section{Ethics approval and consent to participate}

This study was approved by the ethics committee of Angers University Hospital (2021-027) and was conducted in compliance with the Declaration of Helsinki.

\section{Consent for publication}

The two patients presented in Figure 1 gave their signed consent for the publication of these photographs.

\section{Competing interests}

None.

\section{Author details}

${ }^{1}$ Service de Médecine Interne et Immunologie Clinique, Centre Hospitalier Universitaire, 4 rue Larrey, Angers, France. ${ }^{2}$ Mitolab Team-CNRS $6214-$ INSERM 1083-MITOVASC Institute, University of Angers, Angers, France.

${ }^{3}$ Laboratoire d'Hématologie, Centre Hospitalier Universitaire, Angers, France. ${ }^{4}$ Fédération Hospitalo-Universitaire 'Grand Ouest Against Leukemia' (FHU GOAL), Angers, France. ${ }^{5}$ Service de Dermatologie, Centre Hospitalier Universitaire, Angers, France. ${ }^{6}$ CRCINA, INSERM, SFR ICAT, Universités d'Angers, Angers, France. ${ }^{7}$ Département de Pathologie Cellulaire et Tissulaire, Centre Hospitalier Universitaire, Angers, France.

Received: 7 December 2021 Accepted: 6 February 2022

Published online: 16 February 2022 


\section{References}

1. Beck DB, Ferrada MA, Sikora KA, Ombrello AK, Collins JC, Pei W, et al. Somatic mutations in UBA1 and severe adult-onset autoinflammatory disease. N Engl J Med. 2020;383:2628-38.

2. Lacombe V, Kosmider O, Prévost M, Lavigne C, Urbanski G. severe joint involvement in VEXAS syndrome: a case report. Ann Intern Med. 2021. https://doi.org/10.7326/L21-0023.

3. Georgin-Lavialle S, Terrier B, Guedon AF, Heiblig M, Comont T, Lazaro E, et al. Further characterization of clinical and laboratory features occurring in VEXAS syndrome in a large-scale analysis of multicenter case-series of 116 French patients. Br J Dermatol. 2021. https://doi.org/10.1111/bjd. 20805.

4. Huang H, Zhang W, Cai W, Liu J, Wang H, Qin T, et al. VEXAS syndrome in myelodysplastic syndrome with autoimmune disorder. Exp Hematol Oncol. 2021;10:23.

5. Zakine E, Schell B, Battistella M, Vignon-Pennamen M-D, Chasset F, Mahévas T, et al. UBA1 variations in neutrophilic dermatosis skin lesions of patients with VEXAS syndrome. JAMA Dermatol. 2021. https://doi.org/10. 1001/jamadermatol.2021.3344.

6. Poulter JA, Collins JC, Cargo C, de Tute RM, Evans P, Ospina Cardona D. Novel somatic mutations in UBA1 as a cause of VEXAS syndrome. Blood. 2021. https://doi.org/10.1182/blood.2020010286.

7. Lacombe V, Prevost M, Bouvier A, Thépot S, Chabrun F, Kosmider O, et al. Vacuoles in neutrophil precursors in VEXAS syndrome: diagnostic performances and threshold. Br J Haematol. 2021. https://doi.org/10.1111/bjh. 17679.

8. Ferrada MA, Sikora KA, Luo Y, Wells KV, Patel B, Groarke EM, et al. Somatic mutations in UBA1 define a distinct subset of relapsing polychondritis patients With VEXAS. Arthritis Rheumatol. 2021. https://doi.org/10.1002/ art.41743.

9. Comont T, Heiblig M, Rivière E, Terriou L, Rossignol J, Bouscary D, et al. Azacitidine for patients with Vacuoles, E1 Enzyme, X-linked, Autoinflammatory, Somatic syndrome (VEXAS) and myelodysplastic syndrome: data from the French VEXAS registry. Br J Haematol. 2021. https://doi.org/10. 1111/bjh.17893.

\section{Publisher's Note}

Springer Nature remains neutral with regard to jurisdictional claims in published maps and institutional affiliations.

Ready to submit your research? Choose BMC and benefit from:

- fast, convenient online submission

- thorough peer review by experienced researchers in your field

- rapid publication on acceptance

- support for research data, including large and complex data types

- gold Open Access which fosters wider collaboration and increased citations

- maximum visibility for your research: over $100 \mathrm{M}$ website views per year

At BMC, research is always in progress.

Learn more biomedcentral.com/submissions 